\title{
PENGARUH FUNCTIONAL QUALITY DAN TECHNICAL QUALITY TERHADAP KEPUASAN KONSUMEN DAN WORD OF MOUTH COMMUNICATION KONSUMEN LAUNDRYNESIA
}

\author{
Restu Khaliq \\ Dosen Fakultas Dakwah dan Ilmu Komunikasi Universitas Islam Negeri Antasari \\ restu.khaliq@gmail.com
}

\begin{abstract}
The aims of this research were to examine the effect of functional quality and technical quality on customer satisfaction, and the effect of functional quality, technical quality and customer satisfaction to word of mouth communication. This research have been conducted in Laundrynesia with 53 costumer on August 2018 as a respondent. Structural Equation Modeling (SEM) is used as data analysis techniques in this research. The results of the analysis prove that the variables functional quality, technical quality bave a significant influence on customer satisfaction. Functional quality, technical quality and customer satisfaction have a significant influence too to word of mouth communication. All variable's $T$-statistic value are greater than the normal t-distribution table $(1,96)$. Functional quality's T-statistic value on customer satisfaction is 5,174. Technical quality's T-statistic value on customer satisfaction is 4,753. Customer satisfaction's Tstatistic value on word of mouth communication is 10,538. Functional quality's T-statistic value on word of mouth communication is 3,639. Technical quality's T-statistic value on word of mouth communication is 4,251.
\end{abstract}

Key words: Functional Quality, Technical Quality, Customer Satisfaction, Word of Mouth Communication.

Abstrak: Tujuan penelitian ini adalah untuk menguji pengaruh kualitas fungsional dan kualitas teknis terhadap kepuasan pelanggan, dan pengaruh kualitas fungsional, kualitas teknis dan kepuasan pelanggan terhadap word of mouth communication. Penelitian ini dilakukan di Laundrynesia dengan 53 pelanggan pada Agustus 2018 sebagai responden. Structural Equation Modeling (SEM) digunakan sebagai teknik analisis data dalam penelitian ini. Hasil analisis membuktikan bahwa variabel kualitas fungsional, dan kualitas teknis memiliki pengaruh yang signifikan terhadap kepuasan pelanggan. Kualitas fungsional, kualitas teknis dan kepuasan pelanggan juga memiliki pengaruh yang signifikan terhadap word of mouth communication. Nilai T- statistik semua variabel lebih besar daripada tabel distribusi t normal $(1,96)$. Nilai T-statistik kualitas fungsional pada kepuasan pelanggan adalah 5.174. Nilai T- statistik kualitas teknis pada kepuasan pelanggan adalah 4.753. Nilai T- statistik kepuasan pelanggan pada word of mouth communication adalah 10.538. Nilai T- statistik kualitas fungsional pada word of mouth communication adalah 3,639. Nilai Tstatistik kualitas teknis dari word of mouth communication adalah 4.251.

Kata kunci: Functional Quality, Technical Quality, Kepuasan Konsumen, Word of Mouth Communication.

\section{Pendahuluan}

Kompetisi bisnis yang semakin tajam adalah fenomena yang universal dalam dunia bisnis. Untuk memenangkan persaingan bisnis maka perusahaan harus mampu memberikan kepuasan terhadap para konsumennya, terutama perusahaan yang bergerak dalam bidang jasa. Jasa laundry memiliki peluang bisnis yang sangat baik, terlebih masyarakat kota yang semakin sibuk membuat usaha jasa laundry dan $d r y$ clean semakin laris.

Kepuasan konsumen bisa diwujudkan dengan memberikan produk yang mutunya lebih baik, harganya lebih murah, pengantaran dan penyerahan lebih cepat, pelayanannya lebih baik, bila dibandingkan dengan apa yang diperbuat oleh pesaingnya. Sebaliknya ketidakpuasan konsumen akan terjadi apabila produk perusahaan bermutu jelek, harga mahal, pengantaran lambat, pelayanan yang seenaknya. ${ }^{1}$

Kepuasan konsumen akan menciptakan kesempatan bertahan dalam bisnis. Hal ini dikarenakan konsumen yang puas akan mempengaruhi perilaku dan proses pemilihan produk konsumen lain melalui word-of-mouth (WOM) communication. WOM yang positif akan menciptakan kesempatan ekspansi perusahaan lebih cepat. ${ }^{2}$

Pengukuran kepuasan dan hubungannnya dengan konsumen konsumen yang sering

1 E. M. Doelhadi dan Agus Subekti, "Mengukur Tingkat Kepuasan Pelanggan: Perspektif Psikologi Konsumen," Fakultas Psikologi Universitas Airlangga 8, no. 1 (2006).

2 Joanne Silverstein, "Exploiting the Internet: Understanding and Exploiting an Investment in the Internet," Internet Research 8, no. 1 (1998). 
didiskuksikan dalam literatur pemasaran adalah service quality. Sebagian besar pembahasan service quality mengkategorikan dua model service quality yaitu; (1) technical and functional quality model ${ }^{3}$ dan (2) Gap Model/ SERVQUAL. ${ }^{4}$

Beberapa ualasan di atas menginspirasi peneliti untuk melakukan penelitian tentang pengaruh technical dan functional quality terhadap kepuasan konsumen dan word-of-mouth (WOM) communication pada salah satu usaha laundry di Banjarmasin yaitu Laundrynesia.

\section{Literatur Review}

\section{A. Service Quality}

Service quality telah sering dipelajari dalam literatur-literatur pemasaran. Fokus penelitian tentang hal ini mengacu pada model servqual. Berbagai penelitian tentang service quality dengan model servqual yang telah dilakukan berhasil meningkatkan pemahaman tentang service quality itu sendiri. Akan tetapi, hasil tersebut juga tidak lepas dari kritik karena instrumennya berfokus pada proses pemberian layanan, namun tidak mencakup hasil dari pelayanan yang diberikan. ${ }^{5}$

Gronroos mengatakan bahwa service quality yang dirasakan oleh konsumen memiliki dua dimensi: dimensi fungsional/functional quality (atau proses) dan dimensi teknis/technical quality (atau hasil). ${ }^{6}$ Functional quality berfokus pada "bagaimana" pelayanan dilakukan serta dan mempertimbangkan masalah-masalah seperti perilaku staf, kontak konsumen dan kecepatan layanan. Dimensi technical quality berfokus pada "apa" dan menganggap isu-isu tersebut sebagai hasil akhir dari penyediaan layanan.

Guna mendapatkan gambaran yang lebih baik tentang service quality, beberapa penulis menyarankan untuk menilai service quality harus mencakup kedua komponen ini. ${ }^{7}$ Hal ini karena jika service quality dinilai hanya menggunakan

\footnotetext{
${ }^{3}$ Christian Grönroos, "A Service Quality Model and Its Marketing Implications," European Journal of Marketing 18, no. 4 (1984): 36-44.

4 Anantharanthan Parasuraman, Valarie A. Zeithaml, dan Leonard L. Berry, "A Conceptual Model of Service Quality and Its Implications for Future Research," The Journal of Marketing 4, no. 49 (1985): 41-50.

5 W. Glynn Mangold dan Emin Babakus, "Service Quality: The Front- Stage vs The Back- Stage Perspective," Journal of Services Marketing 5, no. 4 (1991): 59-70.

6 Grönroos, "A Service Quality Model and Its Marketing Implications."

7 Julie Baker dan Charles W. Lamb, "Measuring Architectural Design Service Quality," Journal of Professional Services Marketing 10, no. 1 (1994): 89-106.
}

functional quality saja akan menghasilkan validitas prediktif rendah. ${ }^{8}$

\section{B. Kepuasan Konsumen}

Kepuasan adalah respon emosional atau kognitif terhadap harapan, produk, pengalaman konsumsi, setelah melakukan konsumsi. Kepuasan adalah fenomena pasca pembelian. Westbrook dan Reilly yang dikutip oleh Giese \& Cote mengungkapkan bahwa kepuasan merupakan respon emosional terhadap pengalaman dengan produk atau layanan yang telah dibeli. ${ }^{9}$ Oliver berpendapat bahwa kepuasan konsumen adalah komentar konsumen dari pengalaman membeli produk ${ }^{10}$.

Fornell menunjukkan bahwa kepuasan konsumen adalah keseluruhan pengukuran setelah konsumen membeli produk atau menggunakan layanan tersebut ${ }^{11}$. Ini adalah keseluruhan sikap yang dibuat berdasarkan pengalaman, yaitu perbandingan sebelumnya (harapan) dan setelah (perasaan) konsumen menerima layanan (produk). Jika perasaan sebenarnya setelah menerima layanan melebihi harapan sebelum menerima layanan, maka konsumen akan puas; Jika sebaliknya, konsumen tidak akan puas.

\section{Word-of-Mouth (WOM) Communication}

Salah seorang peneliti awal mengenai wordof-mouth communication terhadap perilaku konsumen adalah Arndt. Dia mendefinisikan word-of-mouth communication sebagai komunikasi lisan, orang-ke-orang antara penerima pesan dengan penyampai pesan (komunikator) ${ }^{12}$. Stern mendefinisikan word-of-mouth communication dengan mengkaitkannya kepada periklanan. Stern mengatakan bahwa word-of-mouth communication melibatkan pertukaran pesan lisan atau lisan singkat antara sumber yang berdekatan dan penerima yang berkomunikasi secara langsung dalam kehidupan nyata ${ }^{13}$.

\footnotetext{
${ }^{8}$ Michael D. Richard dan Arthur W. Allaway, "Service Quality Attributes and Choice Behaviour," Journal of Services Marketing 7, no. 1 (1993): 59-68.

9 Joan L. Giese dan Joseph A. Cote, "Defining Consumer Satisfaction," Academy of Marketing Science Review 1, no. 1 (2000): 1-22.

${ }^{10}$ Richard L. Oliver, "What is Customer Satisfaction," Wharton Magazine, 1981.

11 Claes Fornell, "A National Customer Satisfaction Barometer: The Swedish Experience," the Journal of Marketing, 1992, 6-21.

12 Johan Arndt, "Role of Product-Related Conversations in the Diffusion of A New Product," Journal of Marketing Research 19, no. 1 (1967): 291-295.

${ }_{13}$ Barbara B. Stern, "A Revised Communication Model for Advertising: Multiple Dimensions of the Source, the
} 
Harrison Walker dalam Chan mendefinisikannya sebagai komunikasi informal, orang-ke-orang antara sebuah persepsi nonkomersial milik komunikator kepada penerima mengenai merek, produk, organisasi, atau layanan. ${ }^{14}$ Oleh karena itu, word of mouth communication didefinisikan sebagai komunikasi antar konsumen tentang barang dan jasa. Komunikasi ini memiliki kekuatan pesuasif yang kuat dalam penyebaran informasi tentang produk baru ${ }^{15}$.

Word of mouth communication adalah suatu proses di mana seseorang secara informal mempengaruhi tindakan- tindakan dan sikap orang lain. Dalam dunia bisnis, pendapat atau opini positif dari teman dan keluarga jauh lebih persuasif daripada iklan. Oleh sebab itu, banyak perusahaan yang tidak hanya menelaah kepuasan konsumen, namun juga yang menelaah sejauh mana konsumen bersedia merekomendasikan produk perusahaan kepada orang lain.

Masyarakat yang cenderung suka mendengarkan daripada membaca, dalam mencari informasi pun lebih banyak bertanya kepada orang lain yang dipercaya. Oleh karena itu wajar apabila opinion leader mempunyai peran yang sangat penting.

\section{Pengaruh Service Quality terhadap Kepuasan Konsumen}

Kepuasan konsumen merupakan perhatian utama sektor bisnis saat ini, para peneliti selalu melakukan penelitian tentang konsumen terutama terkait dengan kepuasan mereka. Meskipun ada faktor lain seperti harga, kualitas produk dan lain-lain selain kualitas layanan yang menentukan kepuasan konsumen ${ }^{16}$, service quality telah terbukti menjadi penentu terbaik kepuasan konsumen ketika dalam sektor jasa.

Ahmed et al. meneliti hubungan kepuasan pelanggan dengan kualitas layanan dan intensi untuk membeli kembali pada sektor telekomunikasi dengan 5 dimensi servqual (tangibles, responsiveness, empathy, assurance and

Message, and the Recipient," Journal of Advertising 23, no. 2 (1994): 5-15.

14 Yolanda YY Chan dan Eric WT Ngai, "Conceptualising Electronic Word of Mouth Activity: An Input- Process- Output Perspective," Marketing Intelligence \& Planning 29, no. 5 (2011): 488-516.

15 Dwane H. Dean dan Jane M. Lang, "Comparing Three Signals of Service Quality," Journal of Services Marketing 22, no. 1 (2008): 48-58.

${ }^{16}$ Alan Wilson dkk, Services Marketing Integrating Customer Focus across the Firm (McGraw-Hill Education, 2008). reliability) Hasilnya adalah kepuasan konsumen erat hubungannya dengan service quality. ${ }^{17}$ Chau dan Kao menemukan bahwa semua elemen kualitas layanan secara langsung mempengaruhi kepuasan pelanggan. ${ }^{18}$ Cronin dan Taylor membuktikan kualitas layanan merupakan anteseden penting dari kepuasan pelanggan. ${ }^{19}$

\section{E. Pengaruh Kepuasan Konsumen terhadap Word of Mouth Communication}

Persepsi positif yang terbentuk dari konsumen tentang produk/jasa akan menciptakan kepuasan konsumen dan memicu word of mouth communication yang postif pula. ${ }^{20}$ Hal ini mencerminkan bahwa kepuasan konsumen dan word of mouth communication sangat berkaitan. Bahkan Jan, Tahrir yang meneliti pengaruh kepuasan konsumen terhadap word of mouth communication menyatakan bahwa kepuasan konsumen berpengaruh signifikan positif terhadap word of mouth communication konsumen. ${ }^{21}$ Fornell, C menjelaskan hal yang serupa, bahwa memang ada hubungan positif antara kepuasan konsumen terhadap word of mouth communication. 22

\section{F. Pengaruh Service Quality terhadap Word of} Mouth Communication

Pengaruh service quality terhadap word of mouth communication dapat dikonfirmasi dalam beberapa literatur. Hartline dan Jones dalam Sun dan $\mathrm{Qu}$, mempelajari hubungan antara service quality, nilai dan word of mouth

17 Ishfaq Ahmed dkk, "Does Service Quality Affect Students Performance? Evidence from Institutes of Higher Learning," African Journal of Business Management 4, no. 12 (2010): 2527-2533.

18 Vinh Sum Chau dan Yu-Ying Kao, "Bridge over Troubled Water or Long and Winding Road? Gap-5 in Airline Service Quality Performance Measures," Managing Service Quality: An International Journal 19, no. 1 (2009): 106-134.

${ }^{19}$ J. Joseph Cronin Jr dan Steven A. Taylor, "Measuring Service Quality: A Reexamination and Extension," The Journal of Marketing 55, no. 3 (1992): 55-68.

20 Thomas H. Davenport, Jeanne G. Harris, dan Ajay K. Kohli, "How Do They Know Their Customers So Well?” MIT Sloan Management Review 42, no. 2 (2001): 63.

21 Muhammad Tahir Jan, Kalthom Abdullah, dan Ali Shafiq, "The Impact of Customer Satisfaction on Word of Mouth: Conventional Banks of Malaysia Investigated," International Journal of Information Technology \& Computer Science 10, no. 3 (2013): 14-23.

22 Fornell, "A National Customer Satisfaction Barometer." 
communication. ${ }^{23}$ Mereka menemukan bahwa service quality dan nilai yang dirasakan merupakan pemicu word of mouth communication. Selain itu dalam Smith dan Ennew dijelaskan bahwa service quality menghasilkan loyalitas, menarik konsumen, and word of mouth communication yang positif dan pada akhirnya meningkatkan profitabilitas. ${ }^{24}$

\section{Metodologi}

\section{A. Kerangka penelitian}

Tujuan utama penelitian ini adalah untuk mengetahui pengaruh service quality yang terbagi dalam dua dimensi yaitu functional quality dan technical quality terhadap kepuasan konsumen serta pengaruh ketiga variabel tersebut terhadap word of mouth communication. Kerangka penelitian ini dapat dilihat pada Gambar 1.

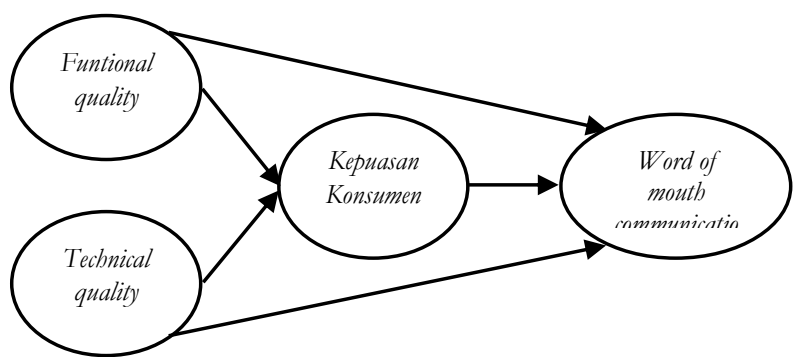

Gambar 1. Kerangka Penelitian

\section{B. Hipotesis}

Penelitian Chau dan Kao mengungkapkan bahwa semua elemen service quality secara langsung mempengaruhi kepuasan pelanggan..$^{25}$ Khusus pada penelitian ini, elemen service quality akan dibagi dalam dua dimensi yaitu; (1) functional quality, dan (2) tecbnical quality sehingga hipotesisnya akan menjadi:

$\mathrm{H}_{1}$ : Functional quality mempunyai pengaruh positif signifikan terhadap kepuasan konsumen.

$\mathrm{H}_{2}$ : Technical quality mempunyai pengaruh positif signifikan terhadap kepuasan konsumen.

Penelitian Jan, Tahrir menyatakan bahwa kepuasan konsumen berpengaruh signifikan

${ }^{23}$ Lucia Bongran Sun dan Hailin Qu, "Is There Any Gender Effect on The Relationship between Service Quality and Word-of-Mouth?," Journal of Travel \& Tourism Marketing 28, no. 2 (2011): 210-224.

${ }^{24}$ Roger Smith dan Christine Ennew, Service Quality and its Impact on Word-of-Mouth Communication in Higher Education: Research Paper Series (Division of Business and Management, University of Nottingham in Malaysia, 2001).

${ }^{25}$ Sum Chau dan Kao, "Bridge over Troubled Water or Long and Winding Road?” positif terhadap word of mouth communication. 26 Penelitian ini mencoba mengkonfirmasi teori tersebut sehingga hipotesis selanjutnya adalah:

$\mathrm{H}_{3}$ : Kepuasan konsumen mempunyai pengaruh positif signifikan terhadap word of mouth communication.

Smith dan Ennew berpendapat bahwa service quality akan mendorong word of mouth communication yang positif dan pada akhirnya meningkatkan profitabilitas. ${ }^{27}$

Dalam penelitian ini service quality yang dibagi menjadi dua dimensi akan diteliti pengaruhnya terhadap word of mouth communication sehingga hipotesisnya menjadi:

$\mathrm{H}_{4}$ : Functional quality mempunyai pengaruh positif signifikan terhadap word of mouth communication.

$\mathrm{H}_{5}$ : Technical quality mempunyai pengaruh positif signifikan terhadap word of mouth communication.

\section{Variabel Penelitian dan Definisi Operasional}

Kuesioner penelitian ini meliputi functional quality, technical quality, kepuasan konsumen, word of mouth communication. Studi ini mengacu pada beberapa peneliti dan kemudian menggabungkannya dengan karakteristik usaha laundry untuk mengembangkan variabel pengukuran berikut, yang ditunjukkan pada Tabel 1.

Penelitian ini menggunakan skala Likert 5 poin (yaitu $1=$ sangat tidak setuju sampai $5=$ sangat setuju) untuk memproses pengukuran kuesioner. Berikut ini adalah tabel operasional variabel penelitian.

\footnotetext{
${ }^{26}$ Jan, Abdullah, dan Shafiq, "The Impact of Customer Satisfaction on Word of Mouth."

27 Smith dan Ennew, Service Quality and its Impact on Word-of-Mouth Communication in Higher Education.
} 
Tabel 1.

Definisi Operasional Variabel dan Indikator

\begin{tabular}{|c|c|c|c|}
\hline Variabel & Definisi Operasional & Indikator & Sumber \\
\hline $\begin{array}{l}\text { Functional } \\
\text { quality }\end{array}$ & $\begin{array}{l}\text { Bagaimana pelayanan } \\
\text { laundry dilakukan dengan } \\
\text { mempertimbangkan } \\
\text { masalah-masalah perilaku } \\
\text { staf, kontak konsumen } \\
\text { dan kecepatan layanan. }\end{array}$ & $\begin{array}{l}\text { - Hasil layanan yang dipesan diserahkan dengan } \\
\text { baik. } \\
\text { - Lamanya waktu tunggu layanan dikerjakan } \\
\text { berada pada level yang bisa diterima. } \\
\text { - Menjawab pertanyaan-pertanyaan konsumen } \\
\text { dengan cepat. }\end{array}$ & $\begin{array}{c}\text { Ali, Faizan } \\
\text { et al. }\end{array}$ \\
\hline $\begin{array}{l}\text { Technical } \\
\text { quality }\end{array}$ & $\begin{array}{l}\text { Apa yang dirasakan oleh } \\
\text { konsumen Laundrrynesia } \\
\text { yang berfokus pada "apa" } \\
\text { dan menganggap isu-isu } \\
\text { tersebut sebagai hasil } \\
\text { akhir dari penyediaan } \\
\text { layanan. }\end{array}$ & $\begin{array}{l}\text { - Peralatan yang baik secara visual. } \\
\text { - Menyelesaikan pekerjaan sesuai waktu yang } \\
\text { dijanjikan. } \\
\text { - Memahami kebutuhan spesial konsumen. } \\
\text { - Konsisten berlaku sopan kepada konsumen. } \\
\text { - Konsumen merasa aman mempercayakan } \\
\text { barangnya. }\end{array}$ & $\begin{array}{l}\text { Wang, } \\
\text { Yonggui } \\
\text { et al. }{ }^{29}\end{array}$ \\
\hline $\begin{array}{l}\text { Kepuasan } \\
\text { konsumen }\end{array}$ & $\begin{array}{l}\text { Persepsi konsumen } \\
\text { Laundrynesia setelah } \\
\text { membandingkan kinerja } \\
\text { layanan yang dirasakan } \\
\text { dengan harapan. }\end{array}$ & $\begin{array}{l}\text { - Konsumen secara keseluruhan merasa puas } \\
\text { dengan layanan. } \\
\text { - Konsumen mendapatkan hasil yang lebih dari } \\
\text { yang diharaapkan. } \\
\text { - Layanan Laundrynesia lebih baik jika } \\
\text { dibandingkan dengan produk layanan sejenis. }\end{array}$ & $\begin{array}{c}\text { Cheng, } \\
\text { Ching } \\
\text { Chan et } \\
\text { al. }{ }^{30}\end{array}$ \\
\hline $\begin{array}{l}\text { Word of } \\
\text { mouth } \\
\text { communi- } \\
\text { cation }\end{array}$ & $\begin{array}{l}\text { Komunikasi informal, } \\
\text { tentang persepsi } \\
\text { komunikator kepada } \\
\text { penerima mengenai } \\
\text { Laundrynesia. }\end{array}$ & $\begin{array}{l}\text { - Konsumen sering menceritakan pengalaman } \\
\text { Anda tentang layanan di Laundynesia. } \\
\text { - Konsumen akan merekomendasikan } \\
\text { Laundrynesia kepada keluarga atau teman yang } \\
\text { memerlukan jasa layanan sejenis. } \\
\text { - Konsumen menceritakan pengalaman postif } \\
\text { Anda kepada keluarga atau teman ketika } \\
\text { berbicara mengenai Laundry. }\end{array}$ & $\begin{array}{c}\text { Yu, } \\
\text { Xiaoyu et } \\
\text { al. } \text {. }^{32}\end{array}$ \\
\hline
\end{tabular}

${ }^{28}$ Faizan Ali dkk, “The Effect of Technical and Functional Quality on Guests' Perceived Hotel Service Quality and Satisfaction: A SEM-PLS Analysis," Journal of Quality Assurance in Hospitality \& Tourism 18, no. 3 (2017): 354-378.

${ }^{29}$ Yonggui Wang, Hing-Po Lo, dan Yongheng Yang, "An Integrated Framework for Service Quality, Customer Value, Satisfaction: Evidence from China's Telecommunication Industry," Information Systems Frontiers 6, no. 4 (2004): $325-340$

${ }^{30}$ Ching Chan Cheng dkk, "A Study on Exploring the Relationship between Customer Satisfaction and Loyalty in The Fast Food Industry: with Relationship Inertia as A Mediator," African Journal of Business Management 5, no. 13 (2011): 5118-5126.

31 Akos Nagy dkk, "Are Opinion Leaders More Satisfied? Results of a SEM Model about the Relationship between Opinion Leadership and Online Customer Satisfaction,” Society and Economy 39, no. 1 (2017): 141-160.

${ }^{32}$ Xiaoyu Yu dkk, "Internet Entrepreneurship and 'The Sharing of Information' in An Internet-of-Things Context: The Role of Interactivity, Stickiness, E-Satisfaction and Word-of-Mouth in Online SMEs' Websites," Internet Research 27, no. 1 (2017): 74-96. 
D. Populasi, Sampel dan Prosedur Pengumpulan Data

Kuesioner penelitian ini disebarkan kepada konsumen Laundrynesia selama periode 2 (dua) bulan mulai Juli dan Agustus 2018. Populasi dari penelitian ini adalah seluruh pelanggan yang menggunakan jasa Laundrynesia pada periode penelitian. Metode sampling yang digunakan adalah sensus atau sampel jenuh, sehingga seluruh populasi akan dijadikan sampel penelitian, oleh karena itu pengisian kuesioner akan menjadi syarat pengambilan barang milik konsumen.

E. Analisis Data

Penelitian ini menggunakan model Partial Least Square (PLS) dengan teknik analisis data menggunakan software smartPLS versi 2.0.M3.

\section{Hasil Penelitian dan Pembahasan}

\section{A. Karakteristik Responden}

Jumlah pengguna jasa Laundrynesia pada bulan Agustus 2018 adalah sebanyak 53 orang. Jumlah ini sekaligus menjadi jumlah responden penelitian yang terbagi menjadi 32 orang lakilaki dan 21 orang perempuan. Ditinjau dari jenis layanan yang digunakan, sebanyak 15 orang menggunakan layanan laundry premium, 19 orang menggunakan layanan cuci kering setrika, 16 orang menggunakan layanan cuci kering dan sisanya 3 orang menggunakan layanan $d r y$ clean karpet.
Tabel 2.

Karakteristik Responden

\begin{tabular}{ll}
\hline & Konsumen \\
\hline Jenis Kelamin & \\
\hline Laki-laki & 32 orang \\
\hline Perempuan & 21 orang \\
\hline Jumlah & 53 orang \\
\hline Produk & \\
\hline Laundry premium & 15 orang \\
\hline Cuci kering setrika & 19 orang \\
\hline Cuci kering & 16 orang \\
\hline Dry clean karpet & 3 orang \\
\hline Jumlah & 53 orang \\
\hline
\end{tabular}

B. Uji Validitas dan Reliabilitas Instrumen Penelitian

Validitas konvergen dan diskriminan indikator dari variabel functional quality, technical quality, kepuasan konsumen, dan word of mouth communication secara keseluruhan menunjukkan hasil yang valid. Hal ini bisa dilihat dari nilai faktor loading untuk mengukur validitas konvergen dan nilai cross loading untuk mengukur validitas diskriminan masing-masing indikator lebih besar dari 0,7 . Berikut adalah rincian hasil perhitungan faktor loading dan cross loading masing-masing indikator:

Tabel 3.

Validitas Indikator Hasil Pengolahan Data

\begin{tabular}{ccccc}
\hline Indikator & $\begin{array}{c}\text { Faktor } \\
\text { Loading }\end{array}$ & $\begin{array}{c}\text { Validitas } \\
\text { Konvergen }\end{array}$ & $\begin{array}{c}\text { Cross } \\
\text { Loading }\end{array}$ & $\begin{array}{c}\text { Validitas } \\
\text { Diskriminan }\end{array}$ \\
\hline FQ.1 & 0,876 & Valid & 0,856 & Valid \\
\hline FQ.2 & 0,801 & Valid & 0,873 & Valid \\
\hline FQ.3 & 0,780 & Valid & 0,723 & Valid \\
\hline TQ.1 & 0,890 & Valid & 0,824 & Valid \\
\hline TQ.2 & 0,845 & Valid & 0,789 & Valid \\
\hline TQ.3 & 0,884 & Valid & 0,842 & Valid \\
\hline TQ.4 & 0,791 & Valid & 0,762 & Valid \\
\hline TQ.5 & 0,862 & Valid & 0,844 & Valid \\
\hline KK.1 & 0,832 & Valid & 0,803 & Valid \\
\hline KK.2 & 0,816 & Valid & 0,795 & Valid \\
\hline KK.3 & 0,847 & Valid & 0,837 & Valid \\
\hline WOM.1 & 0,863 & Valid & 0,858 & Valid \\
\hline WOM.1 & 0,859 & Valid & 0,827 & Valid \\
\hline WOM.1 & 0,857 & Valid & 0,814 & Valid \\
\hline
\end{tabular}


Cronbach's alpha variabel functional quality, technical quality, kepuasan konsumen, dan word of mouth communication nilainya $>0,6$ dan nilai composite reliability seluruh variabel $>0,7$.
Berdasarkan hasil tersebut, seluruh variabel dalam penelitian ini reliabel.

Tabel 4.

Reliabilitas Variabel Hasil Pengolahan Data

\begin{tabular}{cccc}
\hline Variabel & $\begin{array}{c}\text { Cronbach's } \\
\text { alpha }\end{array}$ & $\begin{array}{c}\text { Composite } \\
\text { reliability }\end{array}$ & Keterangan \\
\hline Functional quality & 0,721 & 0,762 & Reliabel \\
\hline Technical quality & 0,733 & 0,792 & Reliabel \\
\hline Kepuasan Konsumen & 0,719 & 0,778 & Reliabel \\
\hline Word of mouth communication & 0,785 & 0,804 & Reliabel \\
\hline
\end{tabular}

Tabel 5.

Total Effect Data Penelitian

\begin{tabular}{cccccc}
\hline & $\begin{array}{c}\text { Original } \\
\text { Sample }\end{array}$ & Sample Mean & $\begin{array}{c}\text { Standard } \\
\text { Deviation }\end{array}$ & T-Statistics & Hipotesis \\
\hline $\mathrm{FQ} \rightarrow \mathrm{KK}$ & 0,540 & 0,339 & 0,023 & 5,174 & Terdukung \\
\hline $\mathrm{TQ} \rightarrow \mathrm{KK}$ & 0,689 & 0,456 & 0,037 & 4,753 & Terdukung \\
\hline $\mathrm{KK} \rightarrow \mathrm{WOM}$ & 0,756 & 0,539 & 0,011 & 10,538 & Terdukung \\
\hline $\mathrm{FQ} \rightarrow \mathrm{WOM}$ & 0,436 & 0,328 & 0,046 & 3,639 & Terdukung \\
\hline $\mathrm{TQ} \rightarrow \mathrm{WOM}$ & 0,449 & 0.316 & 0,079 & 4,251 & Terdukung \\
\hline
\end{tabular}

\section{Uji Hipotesis}

Skema bootstraping akan dilakukan untuk menguji hipotesis. Menentukan sebuah hipotesis terdukung atau tidak, perlu dilihat hasil PLS total effect karena pengujian ini akan melihat efek langsung dan efek tidak langsung variabel independen terhadap variabel dependen. Nilai total effect yang ditunjukkan oleh nilai T-Statistics dengan tingkat kepercayaan 95\% harus di atas 1, 96. Ringkasan hasil pengujian hipotesis melalui skema bootstraping dapat dilihat melalui tabel Total Effect Data Penelitian.

Berdasarkan tabel tersebut, dapat diketahui bahwa:

1. Hipotesis pertama, functional quality mempunyai pengaruh positif signifikan terhadap kepuasan konsumen terdukung dengan nilai T-Statistics sebesar 5,174 lebih besar dari 1, 96. Hal ini berarti functional quality pelayanan laundry dilakukan dengan mempertimbangkan masalah-masalah perilaku staf, kontak konsumen dan kecepatan layanan memberikan pengaruh terhadap kepuasan konsumen pelayanan laundry.

2. Hipotesis kedua, technical quality berpengaruh positif signifikan terhadap kepuasan konsumen terdukung dengan nilai T-Statistics sebesar 4,753 lebih besar dari 1, 96. Hal ini dapat dipahami bahwa technical quality yang dirasakan oleh konsumen Laundrynesia berfokus pada "apa" dan menganggap isu-isu tersebut sebagai hasil akhir dari penyediaan layanan memberikan pengaruh terhadap kepuasan konsumen pelayanan laundry.

3. Hipotesis ketiga terdukung, dengan nilai $T$ Statistics sebesar 10, 538 lebih besar dari 1, 96 menunjukkan bahwa kepuasan konsumen berpengaruh positif signifikan dengan word of mouth communication. Dapat dikatakan bahwa kepuasan konsumen mempengaruhi konsumen untuk mengkomunikasikan secara informal, tentang persepsinya kepada orang lain.

4. Hipotesis keempat functional quality mempunyai pengaruh positif signifikan terhadap word of mouth communication terdukung. Hal ini dibuktikan dengan nilai T-Statistics sebesar 3, 639 lebih besar dari 1, 96. Hal ini berarti functional quality yang dirasakan oleh konsumen Laundrynesia dapat mempengaruhi konsumen untuk mengkomunikasikan secara informal, tentang persepsinya kepada orang lain.

5. Hipotesis kelima terdukung, dengan nilai $T$ Statistics sebesar 4,251 lebih besar dari 1,96 menunjukkan bahwa technical quality berpengaruh positif signifikan dengan word of mouth communication. Hal ini dapat dipahami bahwa technical quality yang 
dirasakan oleh konsumen Laundrynesia dapat mempengaruhi konsumen untuk mengkomunikasikan secara informal, tentang persepsinya kepada orang lain.

\section{Kesimpulan}

Berdasarkan hasil penelitian, diperoleh beberapa kesimpulan sebagai berikut:

1. Functional quality Laundrynesia berpengaruh terhadap kepuasan konsumen Laundrynesia.

2. Technical quality Laundrynesia berpengaruh terhadap kepuasan konsumen Laundrynesia.

3. Kepuasan konsumen Laundrynesia berpengaruh terhadap word of mouth communication konsumen Laundrynesia.

4. Functional quality Laundrynesia berpengaruh terhadap word of mouth communication konsumen Laundrynesia.

5. Technical quality Laundrynesia berpengaruh terhadap word of mouth communication konsumen Laundrynesia.

\section{Daftar Pustaka}

Ahmed, Ishfaq, Muhammad Musarrat Nawaz, Zulfqar Ahmad, Zafar Ahmad, Muhammad Zeeshan Shaukat, Ahmad Usman, dan Naveed Ahmed. "Does Service Quality Affect Students Performance? Evidence from Institutes of Higher Learning." African Journal of Business Management 4, no. 12 (2010): 2527-2533.

Ali, Faizan, Kashif Hussain, Rupam Konar, dan Hyeon-Mo Jeon. "The Effect of Technical and Functional Quality on Guests' Perceived Hotel Service Quality and Satisfaction: A SEM-PLS Analysis." Journal of Quality Assurance in Hospitality \& Tourism 18, no. 3 (2017): 354-378.

Arndt, Johan. "Role of Product-Related Conversations in the Diffusion of a New Product." Journal of Marketing Research 19, no. 1 (1967): 291-295.

Baker, Julie, dan Charles W. Lamb. "Measuring Architectural Design Service Quality." Journal of Professional Services Marketing 10, no. 1 (1994): 89-106.

Chan, Yolanda YY, dan Eric W'T Ngai. "Conceptualising Electronic Word of Mouth Activity: An Input- Process- Output Perspective." Marketing Intelligence \& Planning 29, no. 5 (2011): 488-516.

Cheng, Ching Chan, Shao-I. Chiu, Hsiu-Yuan Hu, dan Ya-Yuan Chang. "A Study on Exploring The Relationship between Customer Satisfaction and Loyalty in The Fast Food Industry: with Relationship
Inertia as A Mediator." African Journal of Business Management 5, no. 13 (2011): 51185126.

Cronin Jr, J. Joseph, dan Steven A. Taylor. "Measuring Service Quality: A Reexamination and Extension." The Journal of Marketing 55, no. 3 (1992): 55-68.

Davenport, Thomas H., Jeanne G. Harris, dan Ajay K. Kohli. "How Do They Know Their Customers So Well?” MIT Sloan Management Review 42, no. 2 (2001): 63.

Dean, Dwane H., dan Jane M. Lang. "Comparing Three Signals of Service Quality." Journal of Services Marketing 22, no. 1 (2008): 48-58.

Doelhadi, E. M., dan Agus Subekti. "Mengukur Tingkat Kepuasan Pelanggan: Perspektif Psikologi Konsumen." Fakultas Psikologi Universitas Airlangga 8, no. 1 (2006).

Fornell, Claes. "A National Customer Satisfaction Barometer: The Swedish Experience." the Journal of Marketing, 1992, 6-21.

Giese, Joan L., dan Joseph A. Cote. "Defining Consumer Satisfaction." Academy of Marketing Science Review 1, no. 1 (2000): 1-22.

Glynn Mangold, W., dan Emin Babakus. "Service Quality: The Front- Stage vs The BackStage Perspective." Journal of Services Marketing 5, no. 4 (1991): 59-70.

Grönroos, Christian. "A Service Quality Model and Its Marketing Implications." European Journal of Marketing 18, no. 4 (1984): 36-44.

Jan, Muhammad Tahir, Kalthom Abdullah, dan Ali Shafiq. "The Impact of Customer Satisfaction on Word of Mouth: Conventional Banks of Malaysia Investigated." International Journal of Information Technology \& Computer Science 10, no. 3 (2013): 14-23.

Nagy, Akos, Ildikó Kemény, Krisztián Sz\Hucs, Judit Simon, dan Viktor Kiss. "Are Opinion Leaders More Satisfied? Results of a SEM Model about the Relationship between Opinion Leadership and Online Customer Satisfaction." Society and Economy 39, no. 1 (2017): 141-160.

Oliver, Richard L. "What is Customer Satisfaction." Wharton Magazine, 1981.

Parasuraman, Anantharanthan, Valarie A. Zeithaml, dan Leonard L. Berry. "A Conceptual Model of Service Quality and Its Implications for Future Research." The Journal of Marketing 4, no. 49 (1985): 41-50.

Richard, Michael D., dan Arthur W. Allaway. "Service Quality Attributes and Choice Behaviour." Journal of Services Marketing 7, no. 1 (1993): 59-68. 
Silverstein, Joanne. "Exploiting the Internet: Understanding and Exploiting an Investment in the Internet." Internet Research 8 , no. 1 (1998).

Smith, Roger, dan Christine Ennew. Service Quality and its Impact on Word-of-Mouth Communication in Higher Education: Research Paper Series. Division of Business and Management, University of Nottingham in Malaysia, 2001.

Stern, Barbara B. "A Revised Communication Model for Advertising: Multiple Dimensions of the Source, the Message, and the Recipient." Journal of Advertising 23, no. 2 (1994): 5-15.

Sum Chau, Vinh, dan Yu-Ying Kao. "Bridge Over Troubled Water or Long and Winding Road? Gap-5 in Airline Service Quality Performance Measures." Managing Service Quality: An International Journal 19, no. 1 (2009): 106-134.

Sun, Lucia Bongran, dan Hailin Qu. "Is There Any Gender Effect on The Relationship between Service Quality and Word-ofMouth?" Journal of Travel \& Tourism Marketing 28, no. 2 (2011): 210-224.

Wang, Yonggui, Hing-Po Lo, dan Yongheng Yang. "An Integrated Framework for Service Quality, Customer Value, Satisfaction: Evidence from China's Telecommunication Industry." Information Systems Frontiers 6, no. 4 (2004): 325-340.

Wilson, Alan, Valarie A. Zeithaml, Mary J. Bitner, dan Dwayne D. Gremler. Services Marketing Integrating Customer Focus Across The Firm. McGraw-Hill Education, 2008.

Yu, Xiaoyu, Sanjit Kumar Roy, Ali Quazi, Bang Nguyen, dan Yuqing Han. "Internet Entrepreneurship and 'The Sharing of Information' in An Internet-of-Things Context: The Role of Interactivity, Stickiness, E-Satisfaction and Word-ofMouth in Online SMEs' Websites." Internet Research 27, no. 1 (2017): 74-96. 